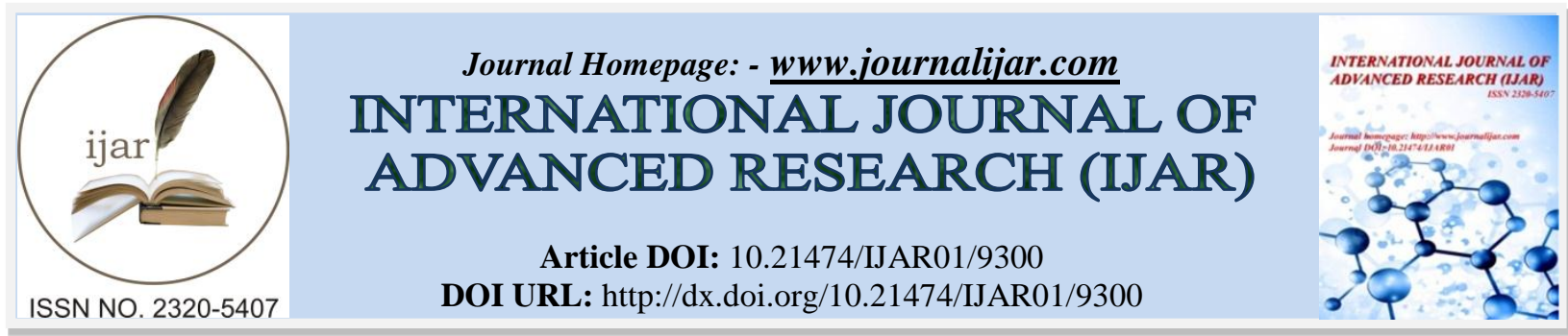

RESEARCH ARTICLE

\title{
PERFORMANCE TASKS IN SET OF COMPETENCIES, TROUBLE, RANGE OF REALISTIC ROLES, AUDIENCE, PRODUCT OR PERFORMANCE AND SCORING RUBRIC (S.T.R.A.P.S) FORMAT AND PUPILS' ACHIEVEMENT IN ENGLISH V.
}

1. Mayondon Elementary School, Los Baños, Laguna, Philippines.

2. Laguna State Polytechnic University-Los Baños Campus, Los Baños, Laguna, Philippines.

\section{Manuscript Info}

\section{Manuscript History}

Received: 15 April 2019

Final Accepted: 17 May 2019

Published: June 2019

Key words:-

performance task, pretest, posttest, scores, assessment.

\begin{abstract}
The study aimed to determine the outcomes of performance tasks in S.T.R.A.P.S format and its relationship to pupils' achievement in English V of Mayondon Elementary School. A quasi-experimental design was utilized to compare the scores of the pre-test and post-test as well as the performance task scores of both comparison and experimental groups. Sixty pupils from experimental and 60 pupils from the comparison groups were the source of the data. Comparison of the mean scores, standard deviation and the Two-sample T-test results were used to determine the aftermaths of the S.T.R.A.P.S. It was found out that the experimental group and comparison groups got a pretest mean score of 20.42, which is interpreted as low. The experimental group got a mean score of 77.37 and 82.68 for the second and third quarters and interpreted as average, while the controlled group got a mean score of 73.68 for the second quarter and 72.40 for the third quarter. There is a significant difference on the results of the post-test between two groups. The posttest is a test similar to the pretest. The test was given to determine the changes in terms of skills and understanding of pupils on the competencies and standards taken from the curriculum guide in English. It was concluded that there is a significant difference between the performance of the pupils from the experimental and comparison groups and the performance task format was found effective. Hence, further research may be conducted about different formats for performance task based assessment.
\end{abstract}

Copy Right, IJAR, 2019,. All rights reserved.

\section{Introduction:-}

Educators are now focused on shifting paradigms to produce learners who are more fortified with real-life skills due to the demands of the $21^{\text {st }}$ Century. The demand of the world is actually performing learners, who can adapt to the real situations in the workplace. It should not be a question of specific information anymore but a question on the utilization of that information. The use of Performance Based Assessment is an excellent way to address this present-day issue in education.

As educators, they know that today's students will enter a workforce in which they do not only acquire information, but also analyze, synthesize, and apply it in addressing new problems, designing solutions, collaborating effectively,

Corresponding Author:-Jermaine D. Alonzo.

Address:- Mavondon Elementarv School. Los Baños.Laguna. Philinpines. 
and communicating persuasively (Hammond, 2013). DepEd Order No.8 series of 2015 issued last April 1, 2015 particularly mentioned that the part of the K-12 curriculum labelled Performance Standards describes the abilities and skills that learners are expected to demonstrate in relation to the content standards and integration of the $21 \mathrm{st}$ century skills. Products, innovations, performances, demonstrations and collaboration are glaringly cited.

The idea of a specific format for performance tasks seems to answer the teachers' difficulty in adjusting to the abovementioned department order. Since the perception towards the implementation of performance task is not a very easy duty, the idea of organizing the task and giving teachers and pupils an easier way to achieve them should be one of the utmost priorities.

Corollary to this, the Department of Education Region IV-A CALABARZON is working towards the achievement of the main goal of the department. The trainings and seminars provided to the teachers and administrators are geared en route for the systematic implementation of the new curriculum. The K-12 curriculum is a national curriculum dedicated to the inkling of leading learners towards the achievement of specific competencies and standards that will make a leaner equipped with skills and knowledge advantageous in the actual working world. By means of this curriculum, the learners are able to do work and activities which are simulation of their future. This makes them feel and experience like a professional that will help them further decide what they want to be in the future. Trainings on non-traditional teaching and assessment are provided and encouraged to be implemented. However, the big question is, "Is it rightfully implemented?"

Due to different reasons and factors, not all teachers are able to plan and give pupils tasks which are simulation of real world. Some give plain projects, simple classroom activities or even provide written exams to be able to grade performance task. These defeat the purpose of the development of skills for real working world.

In reality, students do not really realize why they need to learn specific lessons, understand information and perform numerous skills. When you ask learners of the reasons why they are taught the lessons involved in the curriculum very few will be able to answer near to the real purpose. Learners would often not reply or reply a very general statement depicting their shallow idea about the truth behind learning the courses provided.

Well-planned and thoroughly explained performance task in a specific format will be able to help resolve this issue. Conditioning learners' minds that they are not forever students and that they will soon work for their family to achieve economic stability will surely help in encouraging them more to learn and also to raise level of achievement.

While any performance by a learner might be considered a performance task (e.g., tying a shoe or drawing a picture), it is useful to distinguish between the application of specific and discrete skills (e.g., dribbling a basketball) from genuine performance in context (e.g., playing the game of basketball in which dribbling is one of many applied skills). Hence, when using the term performance tasks, it is referred to more complex and authentic performances (McTighe, 2015).

The current situation in education does not only require a change in teaching styles but also in assessment. Giving an assessment simulating real life situation would help in the idea of strengthening learners' concept of actual application of skills. This will give them an idea of what they really want and what they enjoy and because of this, their choice in the future would be much related to their strengths and capabilities.

Modifications leading towards the improvement of assessment in performance tasks are very much welcomed for it also addresses diversity in learners. Authentic tasks prepared in a specific format would surely help teachers in assessing learners. Upon seeing the needs in the actual work place, this is a key point in focusing on a study bridging the glaring gap and that is to come up with a format for the Performance Task geared towards the improvement of student's output in English.

\section{Objectives Of The Study:-}

This study aimed to determine the outcomes of employing performance tasks in S.T.R.A.P.S format and its relationship to pupils' achievement in English in the grade V level. Specific aims include the following: 1) to determine the level of pupils' achievement in English before the implementation of the format, 2) to assess the pupils' achievement in the experimental and comparison groups, 3) to determine the significant difference between the two groups' achievement in the performance task and posttest. 


\section{Methods:-}

Quasi-experimental design was used to determine the outcomes of the employment of the performance tasks in S.T.R.A.P.S format and the pupils' achievement in English V. A quasi-experiment is an empirical interventional study used to estimate the causal impact of an intervention on target population. In this study, the design was used to further see the effects and impact of employing the proposed format for presenting Performance Tasks.

The study involved two sets of experimental and comparison groups from Mayondon Elementary School, Los Baños, Laguna, which is equivalent to 120 pupils. Match pairing sampling technique was used to prepare the two sets of experimental and comparison groups.Two English teachers were also included in the study. Each teacher handled one set of experimental and comparison group for an equivalent input for both groups. The respondents of the study was selected through match pairing strategy in order to secure a more reliability in terms of comparison of results in the next steps conducted in the study. The implementation of the format was then monitored to secure the employment of the selected sections, especially to the specific respondents.

Two sets were utilized in the conduct of the study. The set 1 is composed of the experimental group which is the section Narra and the controlled group which is the section Tindalo. Moreover, the set 2 is composed of the experimental group Kamagong section and the controlled group, which is section Mahogany.

Scores based on the use of the provided set of rubrics were recorded. Preparatory tasks leading to the major performance tasks were all given in the format to determine the format's effect. Results were documented for further treatment for comparison to determine existing difference.

To determine the results targeted for description and comparison of the sections employed and not employed with the format, the Independent $\mathrm{T}$ test was utilized. There was also the utilization of weighted mean containing the results of the mean scores and the standard deviation to describe learners' performance.

Cohen's D with Effect size was also used in this study. 'Effect size' is a way of quantifying the size of the difference between two groups. It is an important tool explaining the effectiveness of the treatment interpreted as: .8 = large; .5 $=$ moderate; and $.2=$ small. The equivalent interpretations were used to give a more understandable meaning of the computed results for a clearer analysis of the computation output.

\section{Results And Discussion:-}

The study included the employment of a pretest, two preliminary activities per quarter, one major performance task per quarter, and a posttest.

Table 1 presents the pre-test mean scores of the pupils in both groups. This served as the match pairing strategy used for the two sets.

Table 1:-Pre-test mean scores of the pupils in the experimental and comparison groups

\begin{tabular}{|l|l|l|l|l|l|l|}
\hline & \multicolumn{2}{|l|}{ Experimental Group } & \multicolumn{2}{l|}{ Comparison Group } \\
\cline { 2 - 7 } & Mean & SD & $\begin{array}{l}\text { Descriptive } \\
\text { Interpretation }\end{array}$ & Mean & SD & $\begin{array}{l}\text { Descriptive } \\
\text { Interpretation }\end{array}$ \\
\hline Pre-test & 20.42 & 4.01 & Low & 20.42 & 4.01 & Low \\
\hline Legend: $30-40=$ High; $21-29=$ Average; 20 and below = Low
\end{tabular}

The table shows the level achieved by the two groups during the pre-test. Both groups fell into "low" level. The pre-test given was formulated through a set of competencies for the second and third quarter in which the study was implemented.

The results then reflected the below average level of pupils' performance in the competencies intended to be achieved. The table presented that the pupils' skills in writing both comparison and contrast and cause and effect paragraphs falls in just a minimum level. The minitask 1 for the second quarter was given to the pupils in both sets of experimental groups.

The next table shows the results of the first minitask given to the pupils. 
Table 2:-Mean scores of the Minitask 1 for the Second quarter

\begin{tabular}{|l|l|l|l|}
\hline & Mean & SD & $\begin{array}{l}\text { Descriptive } \\
\text { Interpretation }\end{array}$ \\
\hline SET 1 & 22.73 & 2.74 & Average \\
SET 2 & 21.70 & 2.12 & Average \\
\hline
\end{tabular}

Legend: $30-23=$ High; $\quad 15-22=$ Average; 15 and below $=$ Low

Table 2 shows that the first implementation of the format gives minimal results. The results are hanging between average and low and are not far from the scores recorded for the pre-test. The first result was probably due to adjustments both of the teachers and learners involved in the conduct of the study. Also, the teachers may also have some difficulties in explaining and implementing the format to the pupils, seeing the big difference on how they rate the performance task component before and during the implementation. This approves Honey, Pearson, \& Schweingruber's (2014) idea that pupils often ask the question "Why do I need to know this?" and the teacher must be able to answer it properly to make them understand for their adjustment.

Table 3 shows the result of the minitask 2 for the second quarter for both sets of experimental group.

Table 3:-Mean scores of the Minitask 2 for the Second quarter

\begin{tabular}{|l|l|l|l|}
\hline & Mean & SD & $\begin{array}{l}\text { Descriptive } \\
\text { Interpretation }\end{array}$ \\
\hline SET 1 & 21.37 & 2.51 & Low \\
SET 2 & 21.33 & 3.36 & Low \\
\hline
\end{tabular}

Legend: $30-23=$ High; $\quad 15-22=$ Average; 15 and below $=$ Low

This result practically suggests that the two experimental groups have the same skills in writing comparison and contrast paragraphs required for the second task, which falls under low level. Common Core Standards mentioned that students adapt their communication in relation to audience, task, purpose, and discipline. But, this adaptation is not very easy, specially, when they are just newly introduced to a specific skill and form of assessment. Table 4 shows the result of the major performance task for the second quarter of the two experimental groups.

Table 4:-Mean scores of the Major performance task for the Second quarter

\begin{tabular}{|l|l|l|l|}
\hline & Mean & SD & $\begin{array}{l}\text { Descriptive } \\
\text { Interpretation }\end{array}$ \\
\hline SET 1 & 34.40 & 2.04 & High \\
SET 2 & 33.20 & 2.64 & High \\
\hline
\end{tabular}

Legend: $30-40=$ High; $21-29=$ Average; 20 and below $=$ Low

The table above reflects a great improvement of results on both sets of experimental groups. This come to an agreement with Karl Marx's second thesis on Feuerbach: The truth of thinking is proved by practice, not by theory. Table 5 shows the result of the third quarter minitask 1 of the two experimental groups.

Table 5:-Mean scores of the Minitask 1 for the Third quarter

\begin{tabular}{|l|l|l|l|}
\hline & Mean & SD & $\begin{array}{l}\text { Descriptive } \\
\text { Interpretation }\end{array}$ \\
\hline SET 1 & 24.37 & 2.17 & High \\
SET 2 & 25.00 & 2.82 & High \\
\hline
\end{tabular}

Legend: $30-23$ = High;

$15-22=$ Average; $\quad 15$ and below $=$ Low

Table 5 displays the results, which showed a slight difference between two experimental groups. This is still consistent with the former minitask results that the two experimental groups perform almost the same in terms of the skills of outlining which was performed in the task.

Table 6 shows the results for the second minitask for the third quarter of both experimental groups. 
Table 6:-Mean scores of the Minitask 2 for the Third quarter

\begin{tabular}{|l|l|l|l|}
\hline & Mean & SD & $\begin{array}{l}\text { Descriptive } \\
\text { Interpretation }\end{array}$ \\
\hline SET 1 & 24.63 & 2.66 & High \\
SET 2 & 23.17 & 2.68 & High \\
\hline
\end{tabular}

Legend: $30-23=$ High; $\quad 15-22=$ Average; 15 and below $=$ Low

This task is the actual transformation of the outline into the first written draft of the feature article. This task required utilization of the first minitask and then combining the two tasks for the performance of the major one.Table 7 displays the major performance task results for the third quarter.

Table 7:-Mean scores of the Major performance task for the Third quarter

\begin{tabular}{|l|l|l|l|}
\hline & Mean & SD & $\begin{array}{l}\text { Descriptive } \\
\text { Interpretation }\end{array}$ \\
\hline SET 1 & 34.63 & 3.09 & High \\
SET 2 & 33.57 & 3.88 & High \\
\hline
\end{tabular}

Legend: $30-40=$ High;

$$
21-29=\text { Average; } \quad 20 \text { and below }=\text { Low }
$$

After being introduced to the format and having given several evaluations in this format, the pupils were able to perform tasks, which are based on the curriculum standards and competencies. The result still follows the concept of N. Rosaroso and R. Rosaroso that performance-based assessment is viewed as having better possibilities to measure complex skills and communication.

Table 8 shows the comparison of total scores for the performance task component of the experimental and controlled groups.

Table 8:-Performance task mean scores of the pupils in the experimental and comparison groups

\begin{tabular}{|c|c|c|c|c|c|c|}
\hline \multirow[t]{2}{*}{ Performance Task } & \multicolumn{3}{|c|}{ Experimental Group } & \multicolumn{3}{|c|}{ Comparison Group } \\
\hline & Mean & SD & $\begin{array}{l}\text { Verbal } \\
\text { Description }\end{array}$ & Mean & SD & $\begin{array}{l}\text { Verbal } \\
\text { Description }\end{array}$ \\
\hline $\begin{array}{l}\text { Second } \\
\text { Quarter } \\
\text { Third } \\
\text { Quarter }\end{array}$ & $\begin{array}{l}77.37 \\
82.68\end{array}$ & $\begin{array}{l}6.32 \\
7.91\end{array}$ & $\begin{array}{l}\text { Average } \\
\text { Average }\end{array}$ & $\begin{array}{l}73.68 \\
72.40\end{array}$ & $\begin{array}{l}8.34 \\
6.46\end{array}$ & $\begin{array}{l}\text { Low } \\
\text { Low }\end{array}$ \\
\hline
\end{tabular}

The experimental group shows an upward difference of 3.69 points both for the mean of the second quarter. For the third quarter, the experimental group marked 10.28 point advancement. Improvement in the performance of the experimental groups applied with the S.T.R.A.P.S format can be deciphered through the results.

Table 9 shows the Post-test mean scores of the pupils in the experimental and comparison groups.

Table 9:-Post-test mean scores of the pupils in the experimental and comparison groups

\begin{tabular}{|l|l|l|l|l|l|l|}
\hline & \multicolumn{2}{|l|}{ Experimental Group } & \multicolumn{2}{l|}{ Comparison Group } \\
\cline { 2 - 7 } & Mean & SD & $\begin{array}{l}\text { Descriptive } \\
\text { Interpretation }\end{array}$ & Mean & SD & $\begin{array}{l}\text { Descriptive } \\
\text { Interpretation }\end{array}$ \\
\hline Post-test & 29.82 & 5.50 & High & 16.50 & 4.25 & Low \\
\hline
\end{tabular}

Legend: $30-40=$ High; $21-29=$ Average; 20 and below $=$ Low

The table shows a 13.32 mean difference of the two groups. The advancement inclined to the experimental group. The point difference can be interpreted a significant difference due to the more than 10 point progression.

Table 10 shows Test of significant difference between the performance task mean scores of the students in the experimental and comparison groups. 
Table 10:-Test of significant difference between the performance tasks mean scores of the students in the experimental and comparison groups

\begin{tabular}{|l|l|l|l|l|l|}
\hline Performance Task & $\begin{array}{l}\text { Mean } \\
\text { Difference } \\
\text { (Exp vs Comp) }\end{array}$ & $\begin{array}{l}\text { Computed t- } \\
\text { value (df=118) }\end{array}$ & p-value & Effect Size & Interpretation \\
\hline Second Quarter & 3.683 & $2.726^{* *}$ & .007 & 0.43 & Small \\
Third Quarter & 10.283 & $10.283^{* *}$ & $<.0001$ & 1.16 & Large \\
\hline
\end{tabular}

**Significant at $\mathrm{p}$ value $<0.01$

For Cohen's d (Effect Size) Interpretation: 0.80 - Large; 0.50 - Moderate; 0.20 - Small

The achievement of the performance tasks notably increased from the second to third quarter. The result of the posttest also attests to this finding. The result also attests to the effect of the type of assessment used in measuring language skills.

According to Kubanek (1994), the evidence base in classroom language assessment has been growing over the last decade, prompted by a number of developments due to paradigm shifts. The increase of practice and repetitive application of the type of assessment contributes to the development.

Table 11 displays the test of significant difference between the pre-test and post-test mean scores of the pupils in each group.

Table 11:-Test of significant difference between the pre-test and post-test mean scores of the pupils in each group

\begin{tabular}{|l|l|l|l|l|l|}
\hline Group & $\begin{array}{l}\text { Mean } \\
\text { Difference } \\
\text { (Pre-test vs Post- } \\
\text { test) }\end{array}$ & $\begin{array}{l}\text { Computed t- } \\
\text { value (df=59) }\end{array}$ & p-value & Effect Size & Interpretation \\
\hline Comparison & 3.92 & $6.670^{* *}$ & $<.001$ & 0.86 & Large \\
Experimental & -9.40 & $-13.868^{*}$ & $<.001$ & 1.79 & Large \\
\hline
\end{tabular}

$* *$ Significant at $\mathrm{p}$ value $<0.01$

For Cohen’s d (Effect Size) Interpretation: 0.80 - Large; 0.50 - Moderate; 0.20 - Small

Looking at the table, it can be seen that the two groups positively adjusted in the post-test results from their pre-test performance. However, just like most of the results presented, the experimental group showed higher advancement in their performance. This means that the two groups were able to acquire skills and use them but the group using the S.T.R.A.P.S format performed better than the comparison group. This may be an effect of the scaffold and skill by skill assessment of the pupils for a better level of achievement. Table 12 shows the test of significant difference between the post-test mean scores of the pupils in the control and experimental group.

Table 12:-Test of significant difference between the post-test mean scores of the pupils in the control and experimental group

\begin{tabular}{|l|l|l|l|l|l|}
\hline Test & $\begin{array}{l}\text { Mean } \\
\text { Difference } \\
\text { (Exp vs Comp) }\end{array}$ & $\begin{array}{l}\text { Computed t- } \\
\text { value (df=118) }\end{array}$ & -value & Effect Size & Interpretation \\
\hline Post-test & 13.317 & 14.847 & $<.001$ & 1.61 & Large \\
\hline
\end{tabular}

**Significant at $\mathrm{p}$ value $<0.01$

For Cohen's d (Effect Size) Interpretation: 0.80 - Large; 0.50 - Moderate; 0.20 - Small

The table above reflects the large difference between the post-test of the two groups. The large difference of the pretest and post-test of the comparison and the experimental groups in Table 11 may also be added with this result to attain an objective finding. The result suggests that although both groups marked progression from the pre-test to the post-test, the experimental group is still leading in terms of the performance. Performance-Based Assessments help to measure complex learning outcomes that cannot be measured by other means, and provide tools for assessing the process or procedure as well as the product or result of the performing task according to numerous researches. 


\section{Conclusion:-}

Based from the results presented, the following conclusions were formulated:

There is a significant difference between the experimental group's performance before and after the application of the performance task in S.T.R.A.P.S format. This denotes an increase of performance level after the application of the proposed format. Hence, there is a significant difference between the pupils' pretest and posttest mean scores in each group. The experimental group marked a higher result, which makes the hypothesis rejected.

In addition, there is a significant difference between the pupils' achievement in the performance tasks in the experimental and in the comparison groups. This represents that those pupils who are given performance tasks in the S.T.R.A.P.S format performs better than pupils who are not.

This means that the presentation of the performance task also affects pupils' performance in the set tasks.

\section{Recommendations:-}

The researcher came up with the following recommendations parallel to the conclusions made from the study: Performance task component need to be graded through actual tasks stated by the standards and competencies to maximize the set of standards and competencies. Also, interdisciplinary performance tasks need to be done to lessen big performance tasks and also to give emphasis to an existing one. In addition, scaffolding activities need also to be used to achieve a better result in the bigger performance task. Furthermore, grammar and conventions as well as writing and speaking skills need to be given more emphasis in the development of the skills in English. Lastly, further research may be conducted in other subjects to verify the effectiveness of S.T.R.A.P.S. in enhancing the performance of the learners.

\section{References:-}

1. Albanese M. A. and Mitchell. S. (1993). "Problem-based learning: a review of literature on its outcomes and implementation issues," Academic Medicine, vol. 68, no. 1

2. Benjamin A. (2014). The Impact of Performance Assessment on Students' Interest and Academic Performance in Science. University of the West Indies

3. Berger \& Wild (2015). Journal of Commonwealth Law and Legal Education Vol. 10, No. 1, Using Authentic Assessment Techniques In Extra And Co-Curricular Activities (Eccas) To Improve Teaching Standards On Academic Law Programmes

4. Common Core Writing Rubrics and Standards, Grade 5 Retrieved with the permission of EGUSD Curriculum and Professional Learning Department

5. DepEd (2015). Policy guidelines on classroom assessment for the $\mathrm{K}$ to 12 Basic education program. Retrieved from http://www.deped.gov.ph/sites/default/files/order/2015/DO_s2015_08.pdf.

6. DepEd. (2013). $\mathrm{K}$ to 12 curriculum guide English. Retrieved from http://www.deped.gov.ph/sites/default/files/English\%20CG\%20Grade\%201-10\%2001.30.2014.pdf.

7. Espinosa A., Monterola S., \&Punzalan A. (2013). Career-Oriented Performance Tasks in Chemistry: Effects on Students' Critical Thinking Skills, Philippines

8. Espinosa L. (2015). Effective Use of Performance-based Assessments to Identify English Knowledge and Skills of EFL Students in Ecuador, IKIAM Regional University, Tena, Ecuador

9. Hariadi (2017). IOP Conf. Ser.: Mater. Sci. Eng. 180 012164, Instrument Development of Authentic Assessment for Manipulative Fundamental Motor Skill at Elementary School, UniversitasNegeri Medan, Indonesia

10. McTighe, Smith, C., Klenowski, V., \& Gunn, S. (2010). The centrality of teachers' judgement practice in assessment: a study of standards in moderation. Assessment in Education, Virginia

11. Moye J. et al. (2014). Learning by Doing Research, Chesapeake, Vancouver

12. O’Connor, K. (2002). How to grade for learning. California: Corwin Press.

13. Plata, Sterling. (2016).DepEd's 2015 Classroom Assessment Reform: A Policy Analysis, De La Salle University, Manila, Philippines

14. Reese H. (2011). The Learning-by-Doing Principle, West Virginia University

15. Rosaroso R.,.Rosaroso N.,(2015). Performance-based Assessment in Selected Higher Education Institutions in Cebu City, Philippines ,Cebu Normal University, University of San Carlos, Cebu City, Philippines 
16. Rukmini D. (2016). The Authentic Assessment To Measure Students' English Productive Skills Based On 2013 Curriculum, Indonesia

17. Rule C. (2006). “Authentic Assessment," retrieved from http://wik.ed.uiuc.edu/ index.php/Authentic Assessment/.

18. Tomlinson, C and McTighe, J. (2006). Integrating differentiated instruction and understanding by design. Virginia

19. Ulger K. (2018). The Effect of Problem-Based Learning on the Creative Thinking and Critical Thinking Disposition of Students in Visual Arts Education, Cumhuriyet University, kulger@gmail.com

20. VBCPS Continuum of $21^{\text {st }}$ Century Skills." Retrieved from www.vbschools.com/compass/pdfs/VBCPSContinuum.pdf.

21. Wolf R, The Role of Performance Assessment in Studies of Educational Achievement, Teachers College, Columbia University New York, USA

22. Worldwide Instructional System (2005). "Performance Assessment in Online Learning," Proceedings of the 19th Annual Conference on Distance Teaching and Learning

23. Wren D. G. (2010). Assessing 21st-Century Skills With Performance Tasks:The Five-Year Journey of a Large School Division, Virginia

24. Wren D.G., Additional information about Performance Tasks Retrieved from www.vbschools.com/schools/testing/IptFaq.asp. 